\title{
A Empirical Research on Retailer Perception on GST in Vellore District
}

\author{
D. Sheela, R. Murugesan, A. Subangini Devi
}

\begin{abstract}
In this research use empirical study on retailer it show the supply chain of the production and distribution to end user to the collection of tax. Different slab rate are implemented by our government and also facilitate the foreign direct investment of retailers. ANOVA show the retailer perception about GST. The researcher use primary data collection to the retailer and collect the information directly as well as indirectly. The GST avoid cascading effect in the distribution chain and increase the tax payer.
\end{abstract}

Keywords:--empirical, cascading, gst, supply chain.

\section{INTRODUCTION}

Everyone to know about GST and it implementation on $1^{\text {st }}$ July 2017 in India. Retail sector is a one of the main source of tax collection of GST. Retail is a fast growing industry in India maximum income has been generated to our country. Retailer is inter relationship between customer and the tax receiver. Retail as one of the faster growing sector in India, Government also to facilitate the retail industry by foreign direct investment it become increase the growth of retail sector. If retail industry increase paying tax also increase and increase the wealth our country its benefit to our nation as well as people. GST is a biggest taxreform in retail sector then GST is one of the indirect tax to pay to the government indirectly like who consume the product whose who are rich or poor to pay the tax to the government and consumer between intermediates are retailers. In before tax system the manufacture to pay the separate tax such as excess duty and transport duty (octroi) after implement GST avoid all the multiple tax registration. Now only one registration that is GST registration. In GST Input tax credit are available the retailer feel before they pay different tax rate to the single product in different state now remove all the different tax rate in different state to come under single tax to all over India such as $0 \%$ to agricultural items, 3\% for Jewelry items, $5 \%$ for mass consumption, $12 \%$ and $18 \%$ for standard items, $28 \%$ for luxury items. For example who pay the tax $6 \%$ to CGST and 6\% SGST inown state, thenwho's who are in other state who pay $12 \%$ IGST here system is different but tax are same.

"One Nation One Tax One Market"

Supply chain of product to get tax form consumer

Revised Manuscript Received on December 30, 2019.

D. Sheela, Research Scholar, Ph. D. Management (full time), Department of Management Studies, Sri. Vidya Mandir Arts and Science College, Uthangarai, Tamil Nadu, India.

Dr. R. Murugesan,Assistant Professor \& Head of the Department, College, UthangaraiTamil Nadu, India.

Dr. A. Subangini Devi, Assistant Professor, Department of Management Studies, Sri. Vidya Mandir Arts and Science College, Uthangarai, Tamil Nadu, India. Department of Management Studies, Sri. Vidya Mandir Arts and Science

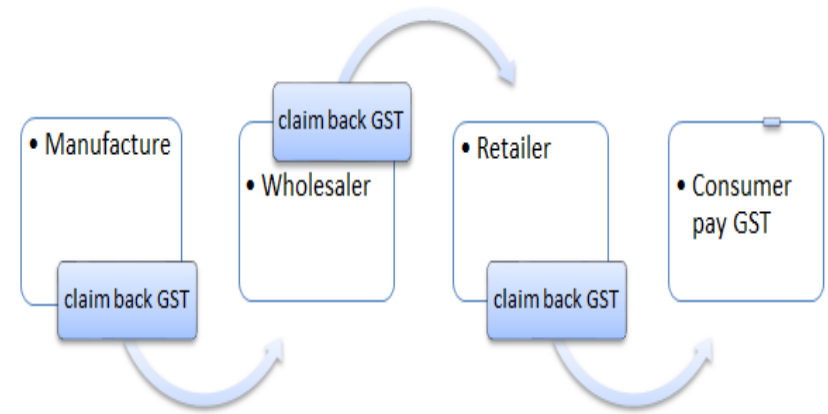

Retailer are come under the category to furnishing of returns under section 39 are GSTR-3B, GSTR-4. GSTR-3B is a monthly return are also known as simple return. GSTR4 is a composite return filling of quarterly return in the period of $18^{\text {th }}$ of the month succeeding quarter. Retailer are pay the tax behalf of the consumer.

Retailer or all business people is have threshold limit for registration his aggregate turnover exceeds Rs. 20 lakhs in a financial year.

Before GST they follow much more tax operation are maintained by all the business person after the all operation are reduced and easy to do they business in the implementation of GST.

In before many of the people are not involve in the tax now all the people are involve in the tax the main supply chain are the retailer to collect the tax form the customers.

GST are reduce tax such product are fan, air cooler, light, water heater, computer, monitor, printer, FMCG products, cloths, within Rs.500 of footwear are reduce tax of 5\% and more than Rs.500 of footwear are increase tax $18 \%$. In the main reason for reducing tax before manufacturing tax are pay $24 \%-26 \%$ of tax now GST introduce $18 \%$ of tax then the price will reduced. So the cost of the product also reduced.

At the same time service tax are increased such as Use of Restaurant, Air condition, TV, vacuum cleaner refrigerator, washing machine, internet jewelry, train, flight, TV service, Wi-Fi, cable TV service, car, perfume, hair die, shaving cream, school fee, insurance are increased $15 \%$ to $18 \%$ of GST tax for the reason who are able to afford tax payer.

\section{REVIEW OF LITERATURE}

Dr. G. H. Barhate (May2017) the researcher says the insight towards GST among trader of rural areas are different categories and their turnover problems and challenges. They reported apathy of implement the GST system particularly in tiny towns where still not a one location process have been planned and implement a till date by knowledgeable authorities.

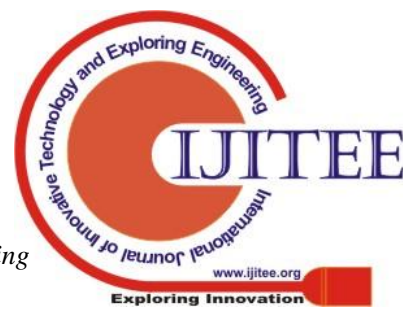


Author use convenience sample to observe the higher response rate perception towards GST.

Poh Jin Goh, Cham Tat Huei, Alexander Guan Meng Tay(2017) This paper as to provide an enhanced thoughtful words for the government of Malaysian consumers perception towards GST. In Malaysian government to apply the GST in April 2015 has exaggerated every member of people in their nation. He says the fiscal issues such as price rises, increasing the cost of living, countrywide budget, economic flux through implementation of GST to Malaysian citizen.

Haiderkhan S. Pathan (2017) His paper give the analysis the GST system in India and some other countries and to understand the HSN (Harmonised System of Nomenclature) and HST (Harmonized Sales Tax)different types of code are used in India. The two countries have implemented the dual tax of GST and most of the countries are follow single unique tax code system. He says the history of GST implementation of India and briefly explain the cascading effect that is tax on tax.

Aakanksha Uppal, Bharti Wadhwa, Anubha Vashisht, Davinder Kaur (2019) the author say the alertness and perception of small business persons towards GST. He says the changes in indirect tax regime and also how far government is successful to get aware SBPs about GST. Researcher used qualitative research design and use 300 sample size. Most of SBP are satisfied with the effort of government as to make the awareness about GST.

\section{OBJECTIVES OF THE STUDY}

- To study the retailer perception about GST

- To study the retailer return of GST

- $\quad$ To study about the GST as effective for retailers

\section{RESEARCH METHODOLOGY \& RESULTS}

The researcher use empirical study gaining knowledge both directly or indirectly observation or experience by primary date collection to the retailers. To find out the perception of retailer use simple random sampling and sampling size 100. ANOVA, Correlation and Chi-square tool are used in the research. Correlation are show the strong relationship between the two variable.

Data Analysis:

\begin{tabular}{|c|c|c|c|c|c|c|}
\hline \multicolumn{7}{|c|}{ Retailers Perception of GST } \\
\hline & $\mathbf{1}$ & 2 & 3 & 4 & 5 & Total \\
\hline $\mathrm{N}$ & 7 & 7 & 7 & 7 & 7 & 35 \\
\hline$\sum \mathrm{X}$ & 72 & 133 & 104 & 207 & 159 & 675 \\
\hline Mean & 10.2857 & 19 & 14.8571 & 29.5714 & 22.7143 & 19.286 \\
\hline$\sum \mathrm{X}^{2}$ & 1120 & 4755 & 2338 & 7085 & 7191 & 22489 \\
\hline Std.Dev. & 7.9522 & 19.27 & 11.4953 & 12.6736 & 24.4248 & 16.6902 \\
\hline \multicolumn{7}{|c|}{ Result Details } \\
\hline \multicolumn{3}{|c|}{ Source } & $S S$ & $d f$ & $M S$ & \\
\hline \multicolumn{3}{|c|}{ Between-treatments } & 1527.7143 & 4 & 381.9286 & $F=1.44243$ \\
\hline \multicolumn{3}{|c|}{ Within-treatments } & 7943.4286 & 30 & 264.781 & \\
\hline \multicolumn{3}{|c|}{ Total } & 9471.1429 & 34 & & \\
\hline
\end{tabular}

The F- ratio value is 1.44243 . The $\mathrm{p}$-value is .244371. The result is not significant at $\mathrm{p}<.05$.

Interpretation:

There is no significant between the GST and development of retailer business.

Chi-Square

\begin{tabular}{|l|c|c|c|c|c|c|}
\hline \multicolumn{7}{|c|}{ Results } \\
\hline & S. D. & $\mathbf{D}$ & $\mathbf{N}$ & $\mathbf{A}$ & $\mathbf{S . ~ A . ~}$ & Row Totals \\
\hline $\begin{array}{l}\text { Good to avoid tax } \\
\text { on tax }\end{array}$ & $\begin{array}{c}1(8.60) \\
{[6.72]}\end{array}$ & $\begin{array}{c}10(9.40) \\
{[0.04]}\end{array}$ & $\begin{array}{c}29(19.80) \\
{[4.27]}\end{array}$ & $\begin{array}{c}45(32.60) \\
{[4.72]}\end{array}$ & $\begin{array}{c}15(29.60) \\
{[7.20]}\end{array}$ & 100 \\
\hline $\begin{array}{l}\text { GST easy to return } \\
\text { filing. }\end{array}$ & $\begin{array}{c}5(8.60) \\
{[1.51]}\end{array}$ & $\begin{array}{c}5(9.40) \\
{[2.06]}\end{array}$ & $\begin{array}{c}10(19.80) \\
{[4.85]}\end{array}$ & $\begin{array}{c}20(32.60) \\
{[4.87]}\end{array}$ & $\begin{array}{c}60(29.60) \\
{[31.22]}\end{array}$ & 100 \\
\hline $\begin{array}{l}\text { GST good for } \\
\text { business. }\end{array}$ & $\begin{array}{c}3(8.60) \\
{[3.65]}\end{array}$ & $\begin{array}{c}2(9.40) \\
{[5.83]}\end{array}$ & $\begin{array}{c}5(19.80) \\
{[11.06]}\end{array}$ & $\begin{array}{c}34(32.60) \\
{[0.06]}\end{array}$ & $\begin{array}{c}56(29.60) \\
{[23.55]}\end{array}$ & 100 \\
\hline $\begin{array}{l}\text { GST for future } \\
\text { business. }\end{array}$ & $\begin{array}{c}19(8.60) \\
{[12.58]}\end{array}$ & $\begin{array}{c}10(9.40) \\
{[0.04]}\end{array}$ & $\begin{array}{c}15(19.80) \\
{[1.16]}\end{array}$ & $\begin{array}{c}44(32.60) \\
{[3.99]}\end{array}$ & $\begin{array}{c}12(29.60) \\
{[10.46]}\end{array}$ & 100 \\
\hline $\begin{array}{l}\text { GST for growth of } \\
\text { the business. }\end{array}$ & $\begin{array}{c}15(8.60) \\
{[4.76]}\end{array}$ & $\begin{array}{c}20(9.40) \\
{[11.95]}\end{array}$ & $\begin{array}{c}40(19.80) \\
{[20.61]}\end{array}$ & $\begin{array}{c}20(32.60) \\
{[4.87]}\end{array}$ & $\begin{array}{c}5(29.60) \\
{[20.44]}\end{array}$ & 100 \\
\hline Column Totals & 43 & 47 & 99 & 163 & 148 & $\mathbf{5 0 0}$ \\
\hline
\end{tabular}

The chi-square statistic is 202.4652. the p-value is $<0.00001$. The result is a significant at $\mathrm{p}<.05$. 


\section{Interpretation:}

There is significant between the GST and it effective for future business. GST implementation is good for the business.

\section{Correlation Coefficient}

Calculation of correlation

$X$ Values

$\sum \quad=100$

Mean $=20$

$\sum(\mathrm{X}-\mathrm{Mx}) 2=\mathrm{SSx} \quad=1192$

$Y$ Values

$\sum \quad=100$

Mean $=20$

$\sum(\mathrm{Y}-\mathrm{My}) 2=\mathrm{SSy} \quad=766$

$X$ and $Y$ Combined

$\mathrm{N}=5$

$\sum(\mathrm{X}-\mathrm{Mx})(\mathrm{Y}-\mathrm{My}) \quad=714$

$R$ Calculation

$\mathrm{r} \quad=\sum((\mathrm{X}-\mathrm{My})(\mathrm{Y}-\mathrm{Mx})) / \sqrt{ }((\mathrm{SSx})(\mathrm{SSy}))$

$\mathrm{r} \quad=714 / \sqrt{ }((1192)(766))=0.7472$

Meta Numeric (cross-check)

$\mathrm{r} \quad=0.7472 \mathrm{Key}$

$\mathrm{X}$ : X Values

Y: Y Values

Mx : Mean of X Values

My : Mean of Y Values

$\mathrm{X}-\mathrm{Mx} \& \mathrm{Y}-\mathrm{My}$ : Deviation scores

$(\mathrm{X}-\mathrm{Mx}) 2$ \& $(\mathrm{Y}-\mathrm{My}) 2$ : Deviation Squared

$(\mathrm{X}-\mathrm{Mx})(\mathrm{Y}-\mathrm{My}) \quad$ : Product of Deviation Scores

The Value of $R$ is 0.7472 .

This is a reasonable positive correlation, which means there is a tendency for high $\mathrm{X}$ variable value go with high $\mathrm{Y}$ variable value (and vice versa).

The value of R2, the coefficient of correlation determined, is 0.5583 .

\section{Interpretation:}

There is a relationship between variable are avoid tax on tax cascading effect it is effective for future business retailers.

\section{FINDINGS}

- Most of the retailer says they avoiding cascading effect during production distribution chain.

- Most of the retailers GST system is no increase the profit in their business.

- GST is not effective to their growth of the business.

- Most of the retailers neither agree nor disagree to their increase the customer flow.

- Most of the retailer agree with the GST implementation good to their business.

- Most of them says GST is effective for future business.

- In ANOVA there is no significant between the GST and development of retailer business profit.
- In correlation analysis there is a relationship between two variable are avoid tax on tax cascading effect it is effective for future business retailers.

- In chi-square there is significant between the GST and it effective for future business. GST implementation is good for the business.

\section{SUGGESTION}

GST show the transparency of the business not for the profit. GST avoiding the cascading effect but their know any change in price level to the product. Retail sector as one of the part of the economic growth, GST is not a part of the retailer benefits. GST is not increase the customer flow only the hard work of retailers. GST is good to their business by avoiding the black money it make digital India it benefit for the future business retailers. GST is improving step by step in future period cashless transaction are realized than the black money fully destroy in our economy.

\section{CONCLUSION}

GST is help to avoid the tax on tax of production distribution chain of the business. By implementation of GST get many changes in the tax system. GST system is an invoice matching by the way to ensure flow of return in various parts of country. By the GST return are use common language to filling the tax it so easy to understand to everyone in the country. GST increase the paying of tax payer and also increase the revenue level of the county. Now most of the retailer are get awareness about GST

\section{REFERENCES}

1. http://ijrar.com/.

2. http://splan.in/blog/tag/scope-of-gst-india

3. https://cleartax.in/s/29th-gst-council-meet-news.

4. https://cleartax.in/s/impact-gst-wholesalers-retailers

5. https://www.deskera.in/gst-benefits-and-impact-onindian-economy.

6. https://www.paisabazaar.com/tax/gst-rates

7. https://www.pwc.in/assets/pdfs/trs/indirect-tax/sectoralupdates/impact-of-gst-fmcg-and-retail-sector.pdf.

8. https://www.socscistatistics.com/tests/

9. www.irjet.net 